\title{
Multiple levels of nitrogen applied to an oligohaline marsh identify a plant community response sequence to eutrophication
}

\author{
Sean A. Graham*, Irving A. Mendelssohn \\ Department of Oceanography and Coastal Sciences, School of the Coast and Environment, Louisiana State University, \\ Energy, Coast \& Environment Building, Baton Rouge, Louisiana 70803, USA
}

\begin{abstract}
We enriched experimental plots in a Sagittaria lancifolia L. dominated oligohaline marsh for $4 \mathrm{yr}$ with one of 4 levels of nitrogen $(\mathrm{N})\left(0,50,200\right.$, or $\left.1200 \mathrm{~kg} \mathrm{~N} \mathrm{ha} \mathrm{yr}^{-1}\right)$ in combination with one of 2 levels of phosphorus (P) (0 or $\left.131 \mathrm{~kg} \mathrm{P} \mathrm{ha}^{-1} \mathrm{yr}^{-1}\right)$ to investigate nutrient limitation of primary production and plant community- and species-level responses to nutrient enrichment. Overall, significant changes in ecosystem structure and function occurred with $\mathrm{N}$ enrichment only; P enrichment had no significant effect alone or in interaction with $\mathrm{N}$. Both 200 and $1200 \mathrm{~kg} \mathrm{~N} \mathrm{ha}^{-1} \mathrm{yr}^{-1} \mathrm{stim}^{-}$ ulated above-ground plant production. Enrichment with $1200 \mathrm{~kg} \mathrm{~N}^{-1} \mathrm{yr}^{-1}$ also increased S. lancifolia tissue N:P ratio, reduced $S$. lancifolia $\mathrm{N}$ and $\mathrm{P}$ resorption during senescence, and altered the relative dominance of the 3 dominant species, but had no effect on species richness. We conclude that (1) $\mathrm{N}$ limits above-ground primary production in this oligohaline marsh; (2) the plant response to $\mathrm{N}$ enrichment is sequential: moderate $\mathrm{N}$ loading stimulated plant production only, while high $\mathrm{N}$ loading maintained the elevated production and also altered plant tissue nutrients and species dominance, but not species richness; (3) N enrichment beyond the assimilation capacity of the vegetation drives changes in ecosystem structure caused by altered plant nutrient cycling; and (4) linear changes in species dominance with increasing $\mathrm{N}$ enrichment suggest that further nutrient enrichment in time or quantity may result in a shift in species dominance and reduced species richness.
\end{abstract}

KEY WORDS: Marsh · Nutrient enrichment · Nitrogen limitation · Primary production · Relative dominance $\cdot$ Nutrient resorption $\cdot$ Louisiana

\section{INTRODUCTION}

Human activities and the resulting manipulation of the global environment have greatly altered the flow and cycling of nutrients across the land-sea margin. Global inputs of reactive nitrogen $(\mathrm{N})$ to coastal waters have increased 20-fold since 1860 (Galloway \& Cowling 2002), and the flux of phosphorus (P) to the world's oceans has increased by nearly 3 -fold in modern times (Howarth et al. 1995, Bennett et al. 2001). As a result, cultural eutrophication, or the biological response to human-induced nutrient over-enrichment, is affecting $>400$ coastal areas around the world (Diaz \& Rosenberg 2008). In the USA alone, $60 \%$ of 138 estuaries, representing $>90 \%$ of the conterminous US estuarine surface area, are moderately to severely affected by eutrophic conditions (Bricker et al. 1999).

The ecological effects of eutrophication are readily apparent in coastal wetlands. Documented effects of nutrient over-enrichment include increased primary production, community metabolism, and consumer activity, reduced species richness and carbon sequestration, altered nutrient cycling and species composition, and expansions of invasive species, to name a few (Mendelssohn 1979, Whigham \& Nusser 1990, Chambers et al. 1999, Morris \& Bradley 1999, Pennings et al. 2002, Silliman \& Bertness 2004, DeLaune et al. 2005, Bertness et al. 2008, and more). A large body of litera- 
ture supports the proposition that in mesohaline (brackish) and polyhaline (salt) marshes, these changes in ecosystem structure and function result from greater $\mathrm{N}$ loading because plant growth in these systems is N-limited (Tyler 1967, Sullivan \& Daiber 1974, Valiela \& Teal 1974, Broome et al. 1975, Patrick \& Delaune 1976, Jefferies \& Perkins 1977, Boyer et al. 2001, Wigand et al. 2004, and more). In comparison, oligohaline (intermediate) marshes have received much less attention, and general conclusions concerning the effects of coastal eutrophication on them are lacking.

Although a few published oligohaline marsh fertilization studies have documented altered plant community structure and/or function induced by $\mathrm{N}$ (DeLaune \& Lindau 1990) and N-P-potassium (N-P-K) enrichment (Gough \& Grace 1997, Slocum \& Mendelssohn 2008), only Crain (2007) applied fully crossed treatments of $\mathrm{N}$ and $\mathrm{P}$ to determine the growth-limiting nutrient or nutrient combination that affects change, in this case $\mathrm{N}$ and $\mathrm{P}$ co-limitation. Moreover, no study has emphasized plant community- and species-level response trajectories resulting from the application of multiple nutrient levels in oligohaline marshes. Additional information is needed to provide more comprehensive answers to fundamental questions concerning the dynamics of oligohaline marsh ecology, including 'Are oligohaline marshes in general co-limited limited by $\mathrm{N}$ and $\mathrm{P}$ ?' and 'What drives ecosystem change once nutrient over-enrichment occurs?'

Though global and national inventories of oligohaline marshes do not exist, the latter represent a major coastal marsh type that requires more intensive study. For example, in Louisiana approximately $23 \%$ (276 000 ha) of all coastal wetlands ( 1.2 million ha) are oligohaline (Turner 1990). This amount alone represents approximately $2.5 \%$ of the total coastal wetland area in the entire conterminous USA (Field et al. 1991). These marshes typically have much greater plant species diversity than their more saline counterparts (Visser et al. 1998, Crain 2007). Multiple studies have documented up to 30 species growing within relatively small sampling areas (Brewer \& Grace 1990, Baldwin \& Mendelssohn 1998). Nutrient over-enrichment is of particular concern in species-rich oligohaline marshes because nutrient excess may alter competitive hierarchies (Brewer \& Grace 1990) and thereby reduce or otherwise modify biodiversity.

The objectives of our research were to determine (1) the nutrient or nutrient combination ( $\mathrm{N}, \mathrm{P}$, or both) that limits primary productivity in an oligohaline marsh, (2) how experimental nutrient manipulation alters plant nutrient cycling and community composition, and (3) whether these changes occur simultaneously or at different rates depending upon the level of nutrient enrichment applied. By addressing these objectives, we tested the general hypothesis that $\mathrm{N}$ and $\mathrm{P}$ co-limit oligohaline marsh primary production. We also identified how enrichment with the limiting nutrient(s) affected individual component species and the vegetative community as a whole, and determined the factors driving changes in community composition following nutrient enrichment. Specifically, we hypothesized that $\mathrm{N}$ limits above-ground biomass production, and because of this, $\mathrm{N}$ enrichment increases above-ground production, alters plant nutrient dynamics, and affects overall community composition. At high $\mathrm{N}$ loading, we hypothesized that $\mathrm{P}$ becomes secondarily limiting when $\mathrm{N}$ limitation is relieved by fertilization, and enrichment with $\mathrm{P}$ in combination with high $\mathrm{N}$ induces additional changes in ecosystem structure and function. We also hypothesized that altered ecosystem structure would result from altered plant nutrient cycling once increased production leveled off.

\section{MATERIALS AND METHODS}

Study area. The coastal waters of Louisiana receive approximately 1.6 million metric tons (t) $\mathrm{N} \mathrm{yr}^{-1}$ and 136500 t P yr $^{-1}$ from the Mississippi-Atchafalaya River complex (Goolsby et al. 1999). The nitrate load ( 950 $000 \mathrm{t} \mathrm{yr}^{-1}$; Goolsby et al. 1999) is now more than twice that discharged in the 1950s (Turner \& Rabalais 1991), driving the development of a persistent and reoccurring near-shore hypoxic area that can exceed $20000 \mathrm{~km}^{2}$ (Rabalais 2002, Turner et. al. 2006; www. gulfhypoxia.net, accessed 3 Dec 2009). Prior to human modification of the Lower Mississippi River, much of this water would follow distributaries and crevasses through the vast coastal wetlands of Louisiana's delta before entering the Gulf of Mexico (Welder 1959). However, following the great flood of 1927, floodcontrol levees were constructed almost continuously to the mouth of the river, and today most of Louisiana's wetlands remain hydrologically isolated from the Mississippi River (Kesel 1988, 2003).

One proposed method for reducing the nutrient load to the northern gulf is to reconnect the Mississippi River to its delta through river diversions (Mitsch et al. 2001, CPRA 2007). The rationale is that coastal wetlands will assimilate nutrients in the diverted river water and reduce the nutrient load to the open waters of the gulf (see Day et al. 2007). However, a major concern with this proposal is that the elevated nutrient load could be a driver of wetland eutrophication over the long term (Parsons et al. 2006).

Study site. To address this concern and our objectives, we investigated the effects of nutrient enrichment in a river-fed oligohaline marsh along the 
west bank of the Tchefuncte River $\left(30^{\circ} 23.205^{\prime} \mathrm{N}\right.$, $\left.90^{\circ} 09.551^{\prime} \mathrm{W}\right)$, approximately $1 \mathrm{~km}$ north of Lake Pontchartrain. Soil at the site is classified as a Kenner series Histosol (euic, thermic Fluvaquentic Medisaprist) formed from herbaceous plant material and characterized as 'very poorly drained, rapidly permeable organic soil' (Trahan et al. 1990). The plant community is highly diverse (Slocum \& Mendelssohn 2008) and is representative of the Oligohaline Mix vegetation type described by Visser et al. (1998). The species mix is dominated by Sagittaria lancifolia L., Eleocharis fallax Weatherby, and Polygonum punctatum Ell. All 3 dominants are perennial (clonal) herbs that emerge, flower, and senesce at similar times during the growing season at this site.

The marsh floods from water-level fluctuations in the Tchefuncte River and Lake Pontchartrain, which are caused primarily by wind shifts during frontal passages, although a $10 \mathrm{~cm}$ microtidal range also affects hydrology (Swenson \& Chuang 1983). Average surface water salinity (1999 to 2006) was approximately $1.6 \mathrm{~g} \mathrm{l}^{-1}$ (LADEQ 2006), indicating oligohaline estuarine conditions (Odum 1988). Nutrient loading to the study marsh is affected by residential development throughout the Tchefuncte River watershed and agriculture in the upper reaches (Table 1). However, Tchefuncte River water has much lower concentrations of inorganic $\mathrm{N}\left(\mathrm{NH}_{3}+\mathrm{NO}_{3}+\right.$ $\mathrm{NO}_{2}$ ), total $\mathrm{N}$, and total $\mathrm{P}$ compared to Mississippi River: 6, 2, and 3 times lower, respectively (Table 1).

Design and sampling. We applied granulated slowrelease fertilizer by surface broadcast for $4 \mathrm{yr}$ to $1 \mathrm{~m}^{2}$ oligohaline marsh plots. Each plot received one of $4 \mathrm{~N}$ levels $\left(0,50,200\right.$, or $1200 \mathrm{~kg} \mathrm{~N} \mathrm{ha}^{-1} \mathrm{yr}^{-1}$ applied as $\mathrm{Nu}$ tralene methylene urea 40-0-0) in combination with one of $2 \mathrm{P}$ levels (0 or $131 \mathrm{~kg} \mathrm{P} \mathrm{ha}{ }^{-1} \mathrm{yr}^{-1}$ applied as Humaphos 0-5-0) to yield 8 treatment combinations in a completely randomized block design. Treatment combinations were replicated in 5 locations (i.e. blocks) spaced 5 to $10 \mathrm{~m}$ apart and parallel to a small drainage canal. Plots were fertilized twice during the growing season in April and July of 2002 through 2005. We delayed sampling until the third and fourth growing seasons after the initiation of nutrient additions (i.e. 2004 or 2005) to increase the chances of detecting treatment effects, as multiple studies have shown that the effects of nutrient enrichment on wetland plant communities become more pronounced with each year of continued enrichment (Valiela et al. 1975, Craft et al. 1995, Kiehl et al. 1997, Crain 2007, Frost et al. 2009). However, we should note that Lindig-Cisneros et al. (2003) found reduced effects of nutrient enrichment on Spartina foliosa total stem length over multiple years of fertilization.

To address Objective 1, we estimated net aboveground primary productivity (NAPP) during the 2005 growing season. Vegetation at this site senesces each
Table 1. Average ambient water quality condition of Tchefuncte River at Madisonville, LA (LA040802_00, Site 0106; LADEQ 2006) and Mississippi River at St. Francisville, LA (LA070201_00, Site 0055; LADEQ 2006) from 1999 to 2006. Potential nutrient loading rate to the study marsh was estimated using water level measurements collected on September 22, 2006 at 3 locations within each $1 \mathrm{~m}^{2}$ plot at mid-tide. Average water level for each plot was correlated by time with 15 min river gauge height data for Tchefuncte River at Madisonville, approximately $1 \mathrm{~km}$ north of the study site (USGS Stn 07375230) to obtain the plot surface elevation relative to the river stage. Relative surface elevation was then averaged across all plots and subtracted from the gauge height data to calculate mean flood depth per plot $\left(0.137 \mathrm{~m} \mathrm{~m}^{-2}\right)$ and flooding frequency $\left(0.59 \mathrm{~d}^{-1}\right)$ for the period of record February 2004 to November 2006. Potential loading rate for each nutrient was then calculated using appropriate unit conversions and the following equation: [nutrient] $\times$ flood depth $\times$ plot area $\times$ flooding frequency

\begin{tabular}{|c|c|c|c|}
\hline Constituent & $\begin{array}{l}\text { Sample } \\
\text { size } \\
\text { (n) }\end{array}$ & $\begin{array}{l}\text { Concentration } \\
\left(\mathrm{mg} \mathrm{N} \text { or } \mathrm{P} \mathrm{l}^{-1}\right)\end{array}$ & $\begin{array}{c}\text { Potential } \\
\text { loading rate } \\
\left(\mathrm{kg} \mathrm{ha}^{-1} \mathrm{yr}^{-1}\right)\end{array}$ \\
\hline \multicolumn{4}{|c|}{ Tchefuncte River } \\
\hline $\mathrm{NH}_{3}-\mathrm{N}$ & 64 & $0.14 \pm 0.01$ & 41 \\
\hline $\mathrm{NO}_{3}+\mathrm{NO}_{2}-\mathrm{N}$ & 81 & $2 \pm 0.01$ & 40 \\
\hline Total N & 82 & $9 \pm 0.03$ & 231 \\
\hline Total P & 90 & $0.11 \pm 0.004$ & 32 \\
\hline \multicolumn{4}{|c|}{ Mississippi River } \\
\hline $\mathrm{NH}_{3}-\mathrm{N}$ & 42 & $0.15 \pm 0.02^{\mathrm{a}}$ & $\mathrm{b}$ \\
\hline $\mathrm{NO}_{3}+\mathrm{NO}_{2}-\mathrm{N}$ & 91 & $1.39 \pm 0.06$ & \\
\hline Total N & 91 & $2.26 \pm 0.07$ & \\
\hline Total P & 89 & $0.21 \pm 0.01$ & \\
\hline \multicolumn{4}{|c|}{ a Average $\mathrm{NH}_{3}$ concentration from 1999 to 2004} \\
\hline \multicolumn{4}{|c|}{$\begin{array}{l}{ }^{\mathrm{b}} \text { The potential nutrient loading rates to this marsh from } \\
\text { diverted Mississippi River water were not included due to } \\
\text { the hypothetical nature of this calculation. However, to } \\
\text { calculate these hypothetical loading rates, recognizing } \\
\text { the assumption that these values apply only if similar } \\
\text { hydrologic conditions are maintained, plug the Missis- } \\
\text { sippi River nutrient concentration into the potential load- } \\
\text { ing rate equation described above }\end{array}$} \\
\hline
\end{tabular}

winter (Baldwin \& Mendelssohn 1998, S. A. Graham pers. obs.), so plant biomass at the beginning of the growing season was zero. Each $1 \mathrm{~m}^{2}$ plot was divided into four $0.25 \mathrm{~m}^{2}$ sub-plots, and all above-ground biomass within a single randomly chosen sub-plot was clipped approximately every $6 \mathrm{wk}$, for a total of 4 biomass harvests per plot. Clipped plant biomass was then separated into live and dead categories, dried to a constant weight at $60^{\circ} \mathrm{C}$, and weighed. Estimates of NAPP were calculated using the Smalley method, which uses changes in both live and dead biomass over time to determine plant production (Smalley 1959). This method is the most widely used in salt marshes for estimating net production, although it is limited in ability to account for biomass export due to tidal flushing and shoot mortality and decomposition between sampling periods (Linthurst \& Reimold 1978). While 
absolute production may be underestimated (Daoust \& Childers 1998), relative differences in production accurately reflect treatment effects.

To address Objectives 2 and 3, we harvested end-ofseason above-ground biomass in October 2004. This end of the growth season biomass harvest had no effect on the following year's NAPP estimation because vegetation at the site senesces each winter. Plant material within a $0.5 \mathrm{~m}^{2}$ quadrat placed in the center of each $1 \mathrm{~m}^{2}$ plot was clipped to the ground surface and separated into live or dead categories by species, then dried at $60^{\circ} \mathrm{C}$ and weighed. Species richness was determined as the total number of species per clipped plot. We calculated species' relative dominance as the percent of species-specific biomass per clipped plot. Differential biomass among species is a good measure of dominance, especially when the plants have similar growth forms. However, because many species occurred at low frequency, we statistically analyzed relative dominance of the 3 dominant species only.

Dried green and senesced leaf and stem tissue from the plant community dominant species, Sagittaria lancifolia, was ground using a Wiley mill and analyzed for total N using a Costech 4010 CHNS/O Elemental Combustion System and total $\mathrm{P}$ using Inductively Coupled Plasma (ICP) Spectrometry (Spectro Ciros) following nitric acid digestion. Tissue $\mathrm{N}$ and $\mathrm{P}$ concentrations were then used to calculate $\mathrm{N}: \mathrm{P}$ ratios (mol:mol) and dry weight-based nutrient resorption efficiencies (i.e. the relative percent difference between live and dead tissue nutrient concentrations; van Heerwaarden et al. 2003).

Statistical analysis. All statistical analyses were conducted using SAS (version 9.1.3, SAS Institute). We used multivariate analysis of variance (MANOVA) (PROC GLM) to determine overall effects of N, P, and their interaction $(\mathrm{N} \times \mathrm{P})$ on the following dependent variables as a group: net above-ground primary production, species richness, relative dominance of the 3 most dominant species (Sagittaria lancifolia, Eleocharis fallax, and Polygonum punctatum), and S. lancifolia tissue $\mathrm{N}$ and $\mathrm{P}$ concentrations, ratios, and resorption efficiencies. Overall treatment effects were determined using the Wilks' lambda test statistic. Where a significant overall effect was identified, individual mixed-model ANOVAs (PROC MIXED) were used to identify the specific dependent variables that contributed to the significant overall effect. Treatment means in PROC MIXED were tested using the least-squares (LS) means procedure with a Tukey-Kramer adjustment to maintain an experiment-wise error rate of $5 \%$. We also used linear and curvilinear regression analyses (PROG REG) to identify predictive relationships with increasing $\mathrm{N}$ enrichment, and Pearson correlation analysis (PROC CORR) to identify bivariate relationships among calculated nutrient resorption efficiencies. When necessary, these data were logarithmically or square root-transformed prior to analysis to improve homogeneity of variance and goodness of fit to a normal distribution. All measures of significance were identified at $\mathrm{p}<0.05$.

\section{RESULTS}

MANOVA results indicated a significant overall $\mathrm{N}$ effect on the various measures of oligohaline marsh ecosystem structure (e.g. species richness and percent dominance) and function (e.g. NAPP and Sagittaria lancifolia tissue nutrient concentrations, ratios, and resorption efficiencies) (Table 2). $\mathrm{P}$ had no significant effect alone or in interaction with $\mathrm{N}$. Thus, only $\mathrm{N}$ effects are discussed. ANOVA results showing the individual dependent variables that contributed to the significant overall $\mathrm{N}$ effect are displayed in Table 2.

\section{Net above-ground primary productivity}

Primary production increased from $1243 \pm 75$ to $1912 \pm 152 \mathrm{~g} \mathrm{~m}^{-2} \mathrm{yr}^{-1}$ with increasing $\mathrm{N}$ enrichment,

Table 2. Multivariate analysis of variance (MANOVA) results showing the overall effects of $\mathrm{N}, \mathrm{P}$, and their interaction on all $(n=10)$ dependent variables as a group. Significant $(p<0.05$, $\mathrm{p}$-values in bold) treatments effects were determined using Wilks' lambda test statistic. Individual ANOVA results are displayed for the $\mathrm{N}$ effect only to identify the specific dependent variables that contributed to the significant overall $\mathrm{N}$ effect

\begin{tabular}{|c|c|c|}
\hline & $\begin{array}{l}\text { Numerator df, } \\
\text { denominator df }\end{array}$ & $\mathrm{p}$ \\
\hline \multicolumn{3}{|l|}{ MANOVA } \\
\hline $\mathrm{N}$ & $30,56.4$ & 0.0001 \\
\hline $\mathrm{P}$ & 10,19 & 0.21 \\
\hline $\mathrm{N} \times \mathrm{P}$ & $30,56.4$ & 0.78 \\
\hline \multicolumn{3}{|l|}{ ANOVA ( $N$ effect) } \\
\hline $\begin{array}{l}\text { (1) Net above-ground } \\
\text { primary production }\end{array}$ & 3,28 & 0.0006 \\
\hline (2) Species richness & 3,28 & 0.87 \\
\hline \multicolumn{3}{|l|}{ (3) Relative dominance } \\
\hline (a) Sagittaria lancifolia & 3,28 & 0.08 \\
\hline (b) Eleocharis fallax & 3,28 & 0.0004 \\
\hline (c) Polygonum punctatum & 3,28 & 0.001 \\
\hline \multicolumn{3}{|l|}{ (4) $S$. lancifolia tissue nutrients } \\
\hline (a) Green-tissue N & 3,28 & 0.03 \\
\hline (b) Green-tissue P & $3,32^{\mathrm{a}}$ & 0.36 \\
\hline (c) Green-tissue molar N:P ratio & 3,28 & 0.0003 \\
\hline (d) $\mathrm{N}$ resorption efficiency & 3,28 & 0.01 \\
\hline (e) P resorption efficiency & 3,28 & 0.004 \\
\hline \multicolumn{3}{|c|}{$\begin{array}{l}\text { a Denominator } \mathrm{df}=32 \text { because the block covariance } \\
\text { parameter estimate } \sigma_{\rho}^{2}=0 . \text { Covariance parameters with } \\
\text { zero variance do not contribute to df computed by the } \\
\text { Satterthwaite method }\end{array}$} \\
\hline
\end{tabular}




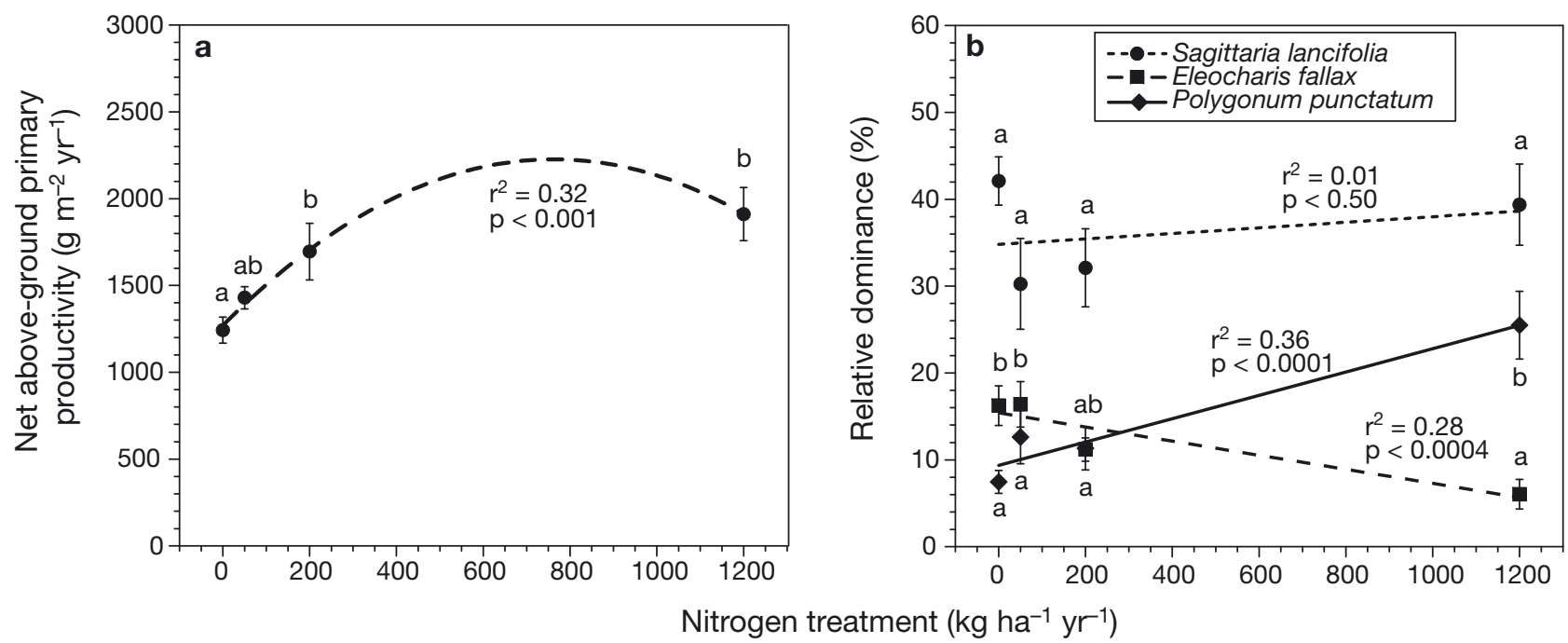

Fig. 1. (a) Macrophyte net above-ground primary productivity (NAPP) and (b) relative dominance of the 3 dominant macrophytes. Means $( \pm \mathrm{SE}, \mathrm{n}=10)$ are averaged over P treatment levels (no significant P-effect). Means separated by different letters are significantly different ( $p \leq 0.05$, Tukey-Kramer multiple comparison test). Different letters in (b) indicate significant differences in relative dominance within (not across) species. Coefficients of determination $\left(\mathrm{r}^{2}\right)$ and $\mathrm{p}$-values represent the best fit to (a) $y=$ $-0.00165 x^{2}+2.5091 x+1270.3(\mathrm{NAPP})$, and (b) $y=0.00319 x+34.810$ (Sagittaria lancifolia), $y=-0.00812 x+15.410$ (Eleocharis fallax), and $y=0.01344 x+9.353$ (Polygonum punctatum)

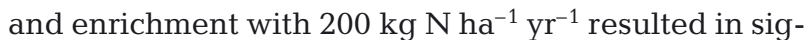
nificantly greater NAPP compared to control plots (Fig. 1a). Further enrichment with $1200 \mathrm{~kg} \mathrm{~N} \mathrm{ha}^{-1} \mathrm{yr}^{-1}$ also increased NAPP compared to the control, but had no additional effect compared to the $200 \mathrm{~kg} \mathrm{~N} \mathrm{ha}^{-1} \mathrm{yr}^{-1}$ treatment. Rather, NAPP increased asymptotically with $\mathrm{N}$ enrichment. The quadratic regression suggests that maximum community primary production occurred within our range of $\mathrm{N}$ enrichment treatments (Fig. 1a).

\section{Community composition}

Within the plant community we distinguished 20 distinct taxonomic categories representing 17 identified species in 11 families (Table 3). $\mathrm{N}$ had no significant effect on species richness. The total number of species per $0.5 \mathrm{~m}^{2}$ clip plot averaged $7.9 \pm 0.2$ regardless of treatment. Although most species were rare and represented only a small fraction of each plot's total biomass, the 3 dominant plant species (Sagittaria lancifolia, Eleocharis fallax, and Polygo-num punctatum) were present in almost every plot, and when combined, accounted for $>60 \%$ of the total aboveground biomass on average. S. lancifolia was clearly the dominant plant, represent- ing $36.0 \pm 2.2 \%$ of the total biomass, regardless of treatment (Fig. 1b). Regression analysis did not identify any significant trends or any variability in $S$. lancifolia relative dominance due to $\mathrm{N}$ enrichment, which indicates that $S$. lancifolia biomass increased at the

Table 3. Plant species identified within study plots and their relative dominance presented as the average (range) for all plots

\begin{tabular}{|lcc|}
\hline Species & Family & $\begin{array}{c}\text { Relative dominance } \\
\text { (\%) (range) }\end{array}$ \\
\hline Sagittaria lancifolia & & $36(12-60)$ \\
Polygonum punctatum & Alismataceae & $14(0-48)^{\mathrm{a}}$ \\
Eleocharis fallax & Polygonaceae & $12(1-31)$ \\
Alternanthera philoxeroides & Cyperaceae & $9(0-29)$ \\
Symphyotrichum subulatum & Ameranthaceae & $4(0-18)$ \\
Vigna luteola & Asteraceae & $2(0-6)$ \\
Lythrum lineare & Fabaceae & $2(0-34)$ \\
Echinochloa crus-galli & Lythraceae & $1(0-4)$ \\
Panicum dichotomiflorum & Poaceae & $<1(0-6)$ \\
Ipomoea sagittata & Poaceae & $<1(0-3)$ \\
Galium tinctorium & Convolvulaceae & $<1(0$ to $<1)$ \\
Phyla nodiflora & Rubiaceae & $<1(0$ to $<1)$ \\
Cyperus odoratus & Verbenaceae & $<1(0$ to $<1)$ \\
Dioda virginiana & Cyperaceae & $<1(0$ to $<1)$ \\
Schoenoplectus tabernaemontani & Rubiaceae & $<1(0$ to $<1)$ \\
Spartina patens & Cyperaceae & $<1(0$ to $<1)$ \\
Ambrosia artemisiifolia & Poaceae & $<1(0$ to $<1)$ \\
Unknown grass $(1)^{\mathrm{b}}$ & Asteraceae & $<1(0$ to $<1)$ \\
Unknown grass $(2)^{\mathrm{b}}$ & Poaceae & $<1(0$ to $<1)$ \\
Unknown spp. & Poaceae & $<1(0$ to $<1)$ \\
& Unknown & \\
a Polygonum punctatum was present in all but 1 plot & \\
bUnidentifiable plant fragments & & \\
& & \\
\hline
\end{tabular}




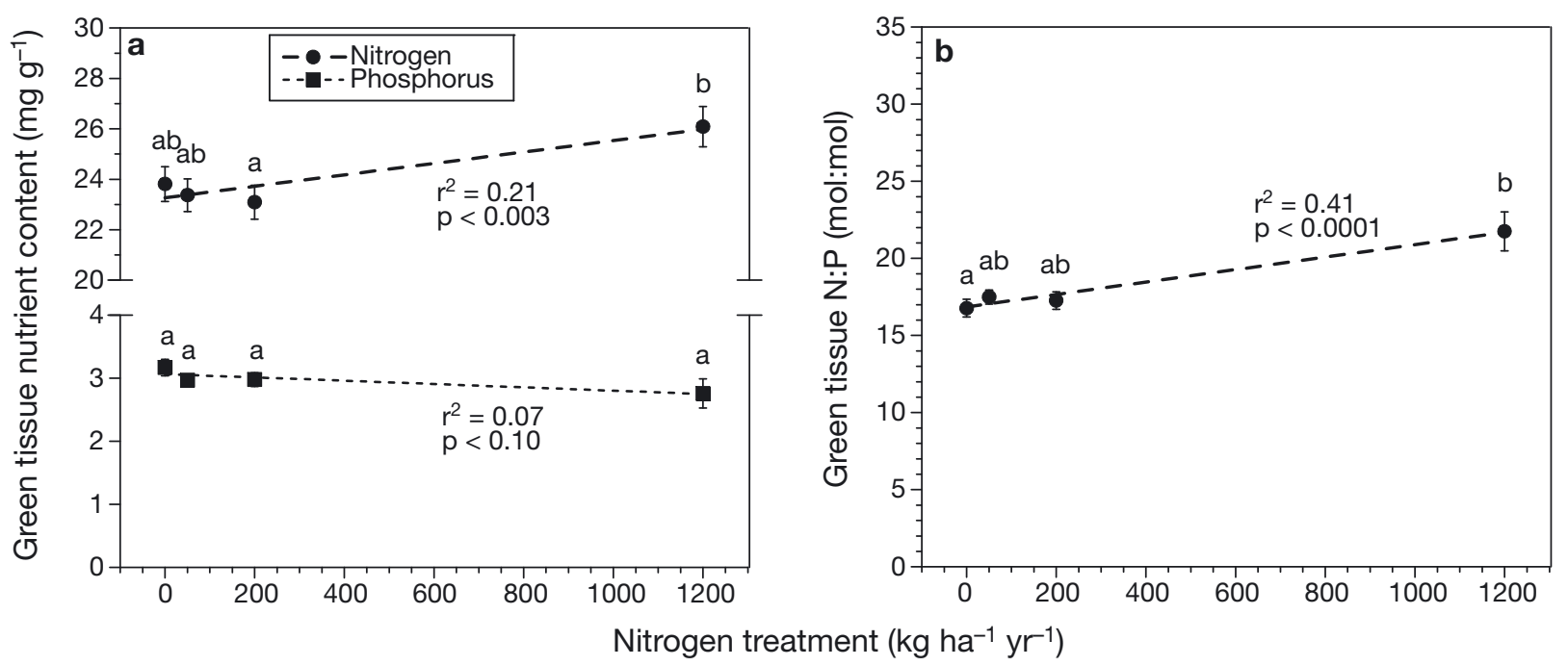

Fig. 2. Sagittaria lancifolia green-tissue (a) N and P content and (b) N:P ratio (mol:mol). Means $( \pm$ SE, $n=10)$ are averaged over $\mathrm{P}$ treatment levels (no significant P-effect). Means separated by different letters are significantly different ( $\mathrm{p} \leq 0.05$, Tukey-Kramer multiple comparison test). Coefficients of determination $\left(\mathrm{r}^{2}\right)$ and $\mathrm{p}$-values are displayed for (a) $y=0.00226 x+23.271$ (N content) and $y=-0.00026 x+3.064$ (P content), and (b) $y=0.00404 x+16.853$ (N:P ratio)

same rate as the plant community. In plots receiving $1200 \mathrm{~kg} \mathrm{~N} \mathrm{ha}^{-1} \mathrm{yr}^{-1}$, the relative dominance of E. fallax fell by $10 \%$ while the dominance of $P$. punctatum increased by $18 \%$ compared to control plots (Fig. 1b). $\mathrm{N}$-induced changes in the relative dominance of both species displayed highly significant linear trends that ultimately resulted in a shift in dominance between the 2 species at the greatest $\mathrm{N}$ enrichment level of $1200 \mathrm{~kg}$ ha ${ }^{-1} \mathrm{yr}^{-1}$.

\section{Sagittaria lancifolia tissue nutrients}

Although the main effect of $\mathrm{N}$ enrichment on greentissue $\mathrm{N}$ was significant (Table 2), no $\mathrm{N}$ treatment level was significantly different from the control (Fig. 2a). Tissue $\mathrm{N}$ was significantly higher only in plots enriched with $1200 \mathrm{~kg} \mathrm{~N} \mathrm{ha}^{-1} \mathrm{yr}^{-1}$ compared to plots enriched with $200 \mathrm{~kg} \mathrm{~N} \mathrm{ha}^{-1} \mathrm{yr}^{-1}$, but both were similar to the control. Green-tissue P content did not change significantly following enrichment with N. However, on average, green-tissue $\mathrm{N}$ and $\mathrm{P}$ concentrations were approximately $10 \%$ higher and $13 \%$ lower, respectively, in plots enriched with $1200 \mathrm{~kg} \mathrm{~N} \mathrm{ha}^{-1} \mathrm{yr}^{-1}$ compared to control plots (Fig. 2a). Overall, tissue $\mathrm{N}$ had a significant positive linear relationship with $\mathrm{N}$ enrichment, but the regression analysis accounted for only $21 \%$ of the variability. The linear relationship between tissue $\mathrm{P}$ and $\mathrm{N}$ enrichment was not significant.

Sagittaria lancifolia N:P ratios increased significantly with $1200 \mathrm{~kg} \mathrm{~N} \mathrm{ha}^{-1} \mathrm{yr}^{-1}$ compared to the control due to the combined non-significant changes in tissue $\mathrm{N}$ and $\mathrm{P}$ (Fig. 2b). Plots enriched with intermediate levels of $\mathrm{N}$
(50 and $200 \mathrm{~kg} \mathrm{ha}^{-1} \mathrm{yr}^{-1}$ ) contained S. lancifolia plants with intermediate tissue N:P ratios that were not statistically different from either the control or the high-N plots. A highly significant positive linear relationship with increasing $\mathrm{N}$ enrichment accounted for $41 \%$ of the variability in tissue $\mathrm{N}: \mathrm{P}$.

In control plots, resorption of $\mathrm{N}$ (NRE) to perennating structures by Sagittaria lancifolia during senescence was little more than half as efficient as P resorption

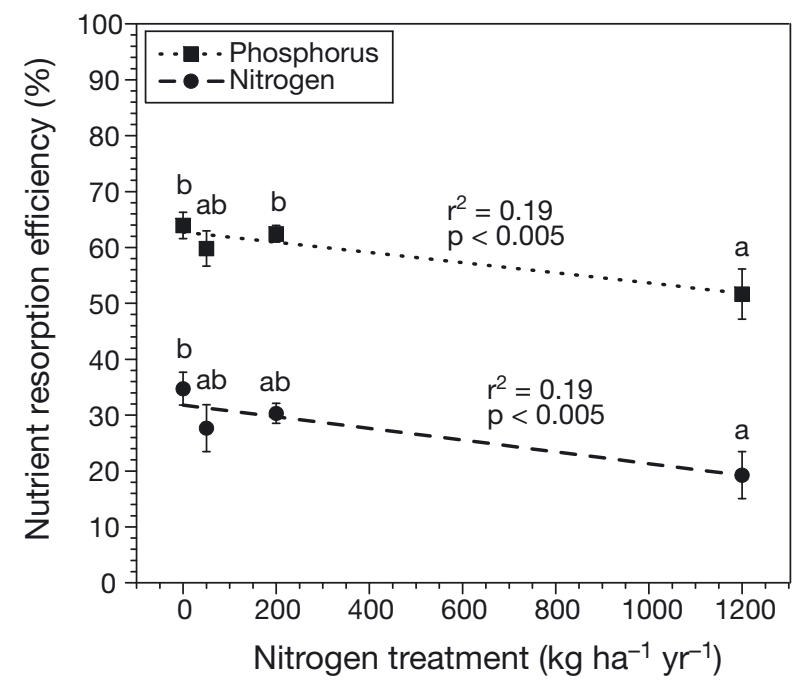

Fig. 3. Sagittaria lancifolia $\mathrm{P}$ and $\mathrm{N}$ resorption efficiencies (PRE and NRE respectively) averaged over P treatment levels. Means separated by different letters are significantly different ( $p \leq 0.05$, Tukey-Kramer multiple comparison test). Coefficients of determination $\left(\mathrm{r}^{2}\right)$ and $\mathrm{p}$-values represent the best fit to $y=-0.00915 x+62.778$ (PRE) and $y=-0.01048 x+$ 31.796 (NRE) 
$(\mathrm{PRE}): \mathrm{NRE}=35 \%, \mathrm{PRE}=64 \%$. Both NRE and PRE decreased following enrichment with $1200 \mathrm{~kg} \mathrm{~N}$ ha $^{-1}$ $\mathrm{yr}^{-1}$ to where $S$. lancifolia resorbed significantly less $\mathrm{N}$ and $\mathrm{P}$ compared to the control plots (Fig. 3). Linear regressions for both NRE and PRE were highly significant, but each explained only $19 \%$ of the variability in nutrient resorption with increasing $\mathrm{N}$ enrichment. There was also a strong correlation between $S$. lancifolia NRE and PRE ( $\mathrm{r}=0.68, \mathrm{p}<0.0001$; data not shown). Higher NRE corresponded to higher PRE, although not at a 1:1 relationship. On average, each $10 \%$ change in NRE corresponded to a $6 \%$ change in PRE.

\section{DISCUSSION}

\section{Nutrient limitation status}

The results from the present study confirm our hypothesis that $\mathrm{N}$ limits primary production in this oligohaline marsh, but refute the hypothesis of secondary P limitation. This conclusion is based primarily on the significant increase (36 to $54 \%$ ) in NAPP after 4 yr of $\mathrm{N}$ enrichment; no changes were detected following $\mathrm{P}$ enrichment, and no additional changes were detected following $\mathrm{N}$ and $\mathrm{P}$ enrichment. Our findings are consistent with a number of experiments in mesohaline (brackish) and polyhaline (salt) marsh systems that have documented increased plant primary production or standing crop following N enrichment (Sullivan \& Daiber 1974, Valiela \& Teal 1974, Cargill \& Jefferies 1984, Boyer et al. 2001, Wigand et al. 2004). Our results are also consistent with studies that have applied $\mathrm{N}$ to oligohaline marshes in Louisiana. Fertilizing with N only, DeLaune \& Lindau (1990) doubled the biomass of Sagittaria lancifolia-dominated marsh. Outside of Louisiana, N enrichment increased Zizaniopsis miliacea (giant cutgrass) biomass by 2-fold in a Georgia tidal freshwater marsh after 2 yr of $\mathrm{N}$ and/or $\mathrm{P}$ enrichment (Frost et al. 2009).

Although our results are consistent with more-saline ecosystems in general, and other oligohaline marshes in Louisiana, they are contrary to results from the only other oligohaline marsh fertilization study designed to determine oligohaline marsh nutrient limitation. Crain (2007) concluded that oligohaline marshes along 2 estuaries in southern Maine were co-limited by $\mathrm{N}$ and $\mathrm{P}$ after $3 \mathrm{yr}$ of combined nutrient enrichment had increased above-ground biomass by $300 \%$. This inconsistency indicates that the relative importance of $\mathrm{P}$ to oligohaline marsh primary production differs between locations. Potential factors contributing to differential nutrient loading include tidal flushing, nutrient source, eutrophic condition, and nutrient inputs (Bricker et al. 1999).
Compared to results from other oligohaline marsh fertilization studies (DeLaune \& Lindau 1990, Crain 2007), we observed a relatively small, but significant, increase in NAPP following enrichment, which can most likely be attributed to differences in ambient marsh productivity. Ambient potential nutrient-loading rates calculated for this marsh in Table 1 coupled with high NAPP $(\sim 1250 \mathrm{~g}$ $\left.\mathrm{m}^{-2} \mathrm{yr}^{-1}\right)$ in control plots indicate that fertile conditions existed at our site prior to $\mathrm{N}$ and/or P enrichment. Furthermore, control plots at our site had approximately $16 \%$ and 35 to $80 \%$ more biomass than the control plots harvested by DeLaune \& Lindau (1990) and Crain (2007), respectively, during comparable biomass harvests in mid-summer. Güsewell \& Bollens (2003) determined that the absolute supply of the limiting nutrient was most important when ambient marsh fertility was low. Therefore, nutrient enrichment should have less of an impact on more productive marshes than those that are naturally less productive.

Under the current assemblage of plant species, NAPP appears to have reached a maximum at enrichment levels $\geq 200 \mathrm{~kg} \mathrm{~N} \mathrm{ha} \mathrm{yr}^{-1}$. NAPP in plots enriched with $200 \mathrm{~kg} \mathrm{~N}$ ha $^{-1} \mathrm{yr}^{-1}$ was not significantly different from NAPP in plots enriched with $1200 \mathrm{~kg} \mathrm{~N}$ $\mathrm{ha}^{-1} \mathrm{yr}^{-1}$, but both were significantly greater than the control. However, we cannot eliminate the possibility that plant production could have been greater at some level of enrichment between 200 and $1200 \mathrm{~kg} \mathrm{~N}$ ha $^{-1}$ $\mathrm{yr}^{-1}$ as suggested by the regression analysis (Fig. 1a). According to the quadratic fit, NAPP would have peaked at approximately $2220 \mathrm{~g} \mathrm{~m}^{-2} \mathrm{yr}^{-1}$ with $760 \mathrm{~g} \mathrm{~N}$ $\mathrm{ha}^{-1} \mathrm{yr}^{-1}$ enrichment. Regardless, the observed reduction in the rate that NAPP increased when enrichment exceeded $200 \mathrm{~kg} \mathrm{~N} \mathrm{ha}^{-1} \mathrm{yr}^{-1}$ is an indication that $\mathrm{N}$ limitation was alleviated and the vegetation's nutrientassimilation capacity was surpassed.

\section{Plant nutrient cycling and community composition}

We measured Sagittaria lancifolia green-tissue N:P ratios of approximately 17 (mol:mol) in control plots, corroborating that $\mathrm{N}$ was the primary limiting nutrient under ambient conditions (N:P < 31 mol:mol; Koerselman \& Meuleman 1996). Adding additional $N$ increased tissue N:P ratios to approximately 22 (mol: $\mathrm{mol})$, but the ratio remained well below that necessary to indicate P limitation (N:P > 36 mol:mol; Koerselman \& Meuleman 1996), even though NAPP measurements indicate that $\mathrm{N}$ limitation was alleviated. Similarly, Frost et al. (2009) were unable to increase Zizaniopsis miliacea $\mathrm{N}: \mathrm{P}$ ratios in an N-limited tidal freshwater marsh to a level beyond the P-limitation threshold. Others have found that vegetation N:P ratios do not correspond with nutrient limitation determined by fer- 
tilization, suggesting that N:P ratios have limited application in understanding the nutrient dynamics of these and perhaps other systems (Morse et al. 2004, Crain 2007). During the present study, a corresponding decrease in $\mathrm{N}$ and $\mathrm{P}$ resorption occurred as tissue $\mathrm{N}: \mathrm{P}$ ratios increased with increasing $\mathrm{N}$ enrichment. Thus, under conditions of high N loading, S. lancifolia conserves less $\mathrm{N}$ and $\mathrm{P}$ and returns more to the soil during senescence, which may explain why tissue N:P ratios did not exceed the P-limitation threshold.

Reduced nutrient resorption efficiency is also an indication that Sagittaria lancifolia's optimal N supply rate has been surpassed. A meta-analysis of fertilization experiments by Aerts (1996) revealed that only about one-third of the species tested responded to increased nutrient availability by lowering nutrient resorption. Concurrent changes in relative dominance of the 2 subdominant species at the $1200 \mathrm{~kg} \mathrm{~N} \mathrm{ha}^{-1} \mathrm{yr}^{-1}$ enrichment level suggest that these species have different optimal $\mathrm{N}$ supply rates than $S$. lancifolia and the plant community as a whole (Bedford et al. 1999), and may explain why the meta-analysis by Aerts (1996) revealed that only a small portion of plant species reduce nutrient resorption under conditions of higher nutrient availability. The linear increase in Polygonum punctatum dominance with increasing $\mathrm{N}$ enrichment indicates that this species prefers a higher nutrient environment, and therefore, would not down-regulate nutrient resorption under such conditions (Fig. 1b). If this linear trend persists with further $\mathrm{N}$ enrichment in time or quantity, a shift in species dominance is likely to occur. P. punctatum could eventually achieve competitive advantage and possibly reduce species richness by displacing species that utilize nutrients less efficiently or that prefer a lower nutrient environment (e.g. Eleocharis fallax). Studies have shown that nutrient-aggressive plants such as Typha spp. and Phragmites australis are capable of reducing species richness by displacement under high nutrient-loading rates (Chambers et al. 1999). In fact, increased Polygonum dominance relative to other component species characterized nutrient enrichment in areas of the Florida Everglades (Vaithiyanathan \& Richardson 1999).

\section{Eutrophication potential}

When viewed collectively, these data show that $\mathrm{N}$ enrichment affects different aspects of the plant community at different rates depending on the loading rate (Table 4). Adding $200 \mathrm{~kg} \mathrm{~N} \mathrm{ha}^{-1} \mathrm{yr}^{-1}$ to this marsh stimulated NAPP, but no other significant changes were detected, showing that at this level of enrichment the additional $\mathrm{N}$ was utilized primarily to increase plant production. Adding $1200 \mathrm{~kg} \mathrm{~N} \mathrm{ha}{ }^{-1} \mathrm{yr}^{-1}$, on the other
Table 4. Eutrophication potential of various functional and structural vegetative characteristics. Initial response level indicates the N enrichment level at which a significant $(p<0.05$, Tukey-Kramer multiple comparison test) change first occurred. nr: no response

\begin{tabular}{|lc|}
\hline Vegetation parameter & $\begin{array}{r}\text { Initial response level } \\
\left(\mathrm{kg} \mathrm{N} \mathrm{ha}^{-1} \mathrm{yr}^{-1}\right)\end{array}$ \\
\hline Net above-ground primary productivity & 200 \\
Tissue N:P ratio & 1200 \\
N and P resorption efficiency & 1200 \\
Relative dominance & 1200 \\
Species richness & $\mathrm{nr}$ \\
\hline
\end{tabular}

hand, not only stimulated NAPP to a similar degree as with $200 \mathrm{~kg} \mathrm{~N} \mathrm{ha}^{-1} \mathrm{yr}^{-1}$, but also increased Sagittaria lancifolia tissue N:P ratios, decreased $S$. lancifolia nutrient resorption efficiencies, and altered the relative dominance of the dominant species. Therefore, $\mathrm{N}$ enrichment beyond that which contributes to plant growth is stored in plant tissues, which in turn, alters plant nutrient-utilization strategies, and ultimately results in changes in plant community structure. Although we detected no significant changes in species richness, Slocum \& Mendelssohn (2008) observed reduced species richness at a nearby site receiving the same $\mathrm{N}$ loading rate $\left(1200 \mathrm{~kg} \mathrm{~N} \mathrm{ha}^{-1} \mathrm{yr}^{-1}\right)$ applied as $\mathrm{N}-\mathrm{P}-\mathrm{K}$ over a comparable time frame.

Similar to the results from the present study, Aerts et al. (1992) explained that the eutrophication process in Nlimited European Sphagnum bogs can be viewed as a chronosequence. The results from their study showed that N enrichment initially increased Sphagnum production and tissue $\mathrm{N}: \mathrm{P}$ ratios. With further $\mathrm{N}$ enrichment in time or quantity, the N:P ratio became so high that $\mathrm{P}$ became limiting, ultimately reducing Sphagnum growth and leading to its disappearance. Contrary to the sequence described by Aerts et al. (1992), we observed an increase in production prior to detecting any changes in nutrient utilization and storage. Furthermore, Sagittaria lancifolia's N:P ratio never indicated P limitation, despite the fact that NAPP measurements indicated that $\mathrm{N}$ limitation had been alleviated. Unlike vascular plants, Sphagnum mosses have no root system, and therefore, are unable to translocate nutrients during senescence via nutrient resorption, at least in the traditional sense (see Rydin \& Clymo 1989). The observed reduction in nutrient resorption in the present study may be a mechanism by which the effects of elevated nutrient loading are counteracted, slowing this sequence of eutrophication and helping Sagittaria lancifolia maintain relative dominance in the short term. Over the long term, however, reduced nutrient resorption could potentially create a positive feedback loop and accelerate eutrophication by returning more $\mathrm{N}$ and $\mathrm{P}$ to the soil during senescence. 


\section{CONCLUSIONS}

We conclude that this marsh and possibly others dominated by Sagittaria lancifolia in Louisiana are $\mathrm{N}$-limited. Therefore, our results refute generalized $\mathrm{N}$ and $\mathrm{P}$ co-limitation of oligohaline marsh primary production and suggest that local factors, such as ambient marsh fertility, may dictate the relative importance of $\mathrm{N}$ and $\mathrm{P}$ in these systems. The various measured plant characteristics indicate that a sequence of eutrophication occurs as enrichment with the limiting nutrient increases. This marsh is capable of assimilating at least $200 \mathrm{~kg} \mathrm{ha}^{-1} \mathrm{yr}^{-1}$ more $\mathrm{N}$ than the current loading rate without significant changes to ecosystem structure. Increased NAPP following N addition, while significant, was rather small in magnitude, and there were signs that $\mathrm{N}$ limitation was alleviated. $\mathrm{N}$ enrichment above this amount (i.e. $1200 \mathrm{~kg} \mathrm{~N} \mathrm{ha}^{-1} \mathrm{yr}^{-1}$ ) surpassed the nutrient-assimilation capacity of the vegetation, altering plant nutrient cycling, which caused changes in ecosystem structure. This suggests that oligohaline marshes such as this one may have limited potential for removing excess nutrients, even if some of the species relax their nutrient resorption efficiencies. Although it is unlikely that natural sources of eutrophication (e.g. the Mississippi River) will surpass our experimental $\mathrm{N}$-loading rates in magnitude, the cumulative load over the long term (decades) could be much higher, and result in equivalent or more pronounced changes in ecosystem structure and function.

Acknowledgments. Funding for this research was provided by a grant from the National Oceanic and Atmospheric Administration's (NOAA) Center for Sponsored Coastal Ocean Research (CSPOR). We thank J. Baustian, C. Stagg, and J. Roberts for their assistance in the field, and M. Slocum for help in analyzing data. We also thank R. DeLaune, M. Slocum, D. Blouin, and 3 anonymous reviewers whose constructive comments improved upon an earlier version of this manuscript.

\section{LITERATURE CITED}

Aerts R (1996) Nutrient resorption from senescing leaves of perennials: are there general patterns? J Ecol 84:597-608

Aerts R, Wallen B, Malmer N (1992) Growth-limiting nutrients in Sphagnum-dominated bogs subject to low and high atmospheric nitrogen supply. J Ecol 80:131-140

Baldwin AH, Mendelssohn IA (1998) Response of two oligohaline marsh communities to lethal and nonlethal disturbance. Oecologia 116:543-555

Bedford BL, Walbridge MR, Aldous A (1999) Patterns in nutrient availability and plant diversity of temperate North American wetlands. Ecology 80:2151-2169

Bennett EM, Carpenter SR, Caraco NF (2001) Human impact on erodable phosphorus and eutrophication: a global perspective. Bioscience 51:227-234

Bertness MD, Crain C, Holdredge C, Sala N (2008) Eutrophication and consumer control of New England salt marsh primary productivity. Conserv Biol 22:131-139
Boyer KE, Fong P, Vance RR, Ambrose RF (2001) Salicornia virginica in a southern California salt marsh: seasonal patterns and a nutrient-enrichment experiment. Wetlands 21:315-326

Brewer JS, Grace JB (1990) Plant community structure in an oligohaline tidal marsh. Vegetatio 90:93-107

Bricker SB, Clement CG, Pirhalla DE, Orlando SP, Farrow DRG (1999) National estuarine eutrophication assessment: effects of nutrient enrichment in the nation's estuaries. NOAA, National Ocean Service, Special Projects Office and the National Centers for Coastal Ocean Science, Silver Spring, MD

Broome SW, Woodhouse WW, Seneca ED (1975) The relationship of mineral nutrients to growth of Spartina alterniflora in North Carolina. II. The effects of N, P, and Fe fertilizers. Soil Sci Soc Am J 39:301-307

Cargill SM, Jefferies RL (1984) Nutrient limitation of primary production in a sub-arctic salt-marsh. J Appl Ecol 21: 657-668

Chambers RM, Meyerson LA, Saltonstall K (1999) Expansion of Phragmites australis into tidal wetlands of North America. Aquat Bot 64:261-273

Coastal Protection and Restoration Authority (CPRA) of Louisiana (2007) Integrated ecosystem restoration and hurricane protection: Louisiana's comprehensive master plan for a sustainable coast. CPRA, Baton Rouge, LA

Craft CB, Vymazal J, Richardson CJ (1995) Response of Everglades plant-communities to nitrogen and phosphorus additions. Wetlands 15:258-271

Crain CM (2007) Shifting nutrient limitation and eutrophication effects in marsh vegetation across estuarine salinity gradients. Estuaries Coasts 30:26-34

$>$ Daoust RJ, Childers DL (1998) Quantifying aboveground biomass and estimating net aboveground primary production for wetland macrophytes using a non-destructive phenometric technique. Aquat Bot 62:115-133

> Day JW, Boesch DF, Clairain EJ, Kemp GP and others (2007) Restoration of the Mississippi Delta: lessons from Hurricanes Katrina and Rita. Science 315:1679-1684

DeLaune RD, Lindau CW (1990) Fate of ${ }^{15} \mathrm{~N}$ labeled nitrogen in a Sagittaria lancifolia L. Gulf Coast marsh. J Freshw Ecol 5:265-268

DeLaune RD, Pezeshki SR, Jugsujinda A (2005) Impact of Mississippi River freshwater reintroduction on Spartina patens marshes: responses to nutrient input and lowering of salinity. Wetlands 25:155-161

- Diaz RJ, Rosenberg R (2008) Spreading dead zones and consequences for marine ecosystems. Science 321:926-929

Field DW, Reyer AJ, Genoves PA, Shearer BD (1991) Coastal wetlands of the United States: an accounting of a valuable national resource. Special NOAA 20th Anniversary Report. National Oceanic and Atmospheric Administration and United States Fish and Wildlife Service, Washington, DC

Frost JW, Schleicher T, Craft C (2009) Effects of nitrogen and phosphorus additions on primary production and invertebrate densities in a Georgia (USA) tidal freshwater marsh. Wetlands 29:196-203

Galloway JN, Cowling EB (2002) Reactive nitrogen and the world: 200 years of change. Ambio 31:64-71

Goolsby DA, Battaglin WA, Lawrence GB, Artz RS and others (1999) Flux and sources of nutrients in the MississippiAtchafalaya River basin. Topic 3. Report for the integrated assessment of hypoxia in the Gulf of Mexico. National Oceanic and Atmospheric Administration Coastal Ocean Program, Silver Spring, MD

Gough L, Grace JB (1997) The influence of vines on an oligohaline marsh community: results of a removal and fertilization study. Oecologia 112:403-411 
Güsewell S, Bollens U (2003) Composition of plant species mixtures grown at various N: P ratios and levels of nutrient supply. Basic Appl Ecol 4:453-466

Howarth R, Jensen WH, Marino R, Postma H (1995) Transport to and processing of $\mathrm{P}$ in near-shore and oceanic waters. In: Tiessen $\mathrm{H}$ (ed) Phosphorus in the global environment: transfers, cycles and management. Scope 54. Wiley, Chichester, p 323-345

Jefferies RL, Perkins N (1977) The effects on the vegetation of the additions of inorganic nutrients to salt marsh soils at Stiffkey, Norfolk. J Ecol 65:867-882

Kesel RH (1988) The decline in the suspended-load of the lower Mississippi River and its influence on adjacent wetlands. Environ Geol Water Sci 11:271-281

Kesel RH (2003) Human modifications to the sediment regime of the lower Mississippi River flood plain. Geomorphology 56:325-334

Kiehl K, Esselink P, Bakker JP (1997) Nutrient limitation and plant species composition in temperate salt marshes. Oecologia 111:325-330

Koerselman W, Meuleman AFM (1996) The vegetation N:P ratio: a new tool to detect the nature of nutrient limitation. J Appl Ecol 33:1441-1450

Lindig-Cisneros R, Desmond J, Boyer KE, Zedler JB (2003) Wetland restoration thresholds: can a degradation transition be reversed with increased effort? Ecol Appl 13: 193-205

Linthurst RA, Reimold RJ (1978) Evaluation of methods for estimating the net aerial primary productivity of estuarine angiosperms. J Appl Ecol 15:919-931

Louisiana Department of Environmental Quality (LADEQ) (2006) Ambient surface water quality monitoring network. Water Quality Assessment Division. LADEQ, Baton Rouge, LA

Mendelssohn IA (1979) Influence of nitrogen level, form, and application method on the growth-response of Spartina alterniflora in North Carolina. Estuaries 2:106-112

Mitsch WJ, Day JW, Gilliam JW, Groffman PM, Hey DL, Randall GW, Wang NM (2001) Reducing nitrogen loading to the Gulf of Mexico from the Mississippi River Basin: strategies to counter a persistent ecological problem. Bioscience 51:373-388

Morris JT, Bradley PM (1999) Effects of nutrient loading on the carbon balance of coastal wetland sediments. Limnol Oceanogr 44:699-702

> Morse JL, Megonigal JP, Walbridge MR (2004) Sediment nutrient accumulation and nutrient availability in two tidal freshwater marshes along the Mattaponi River, Virginia, USA. Biogeochemistry 69:175-206

Odum WE (1988) Comparative ecology of tidal freshwater and salt marshes. Annu Rev Ecol Syst 19:147-176

Parsons ML, Dortch Q, Turner RE, Rabalais NR (2006) Reconstructing the development of eutrophication in Louisiana salt marshes. Limnol Oceanogr 51:534-544

Patrick WH, Delaune RD (1976) Nitrogen and phosphorus utilization by Spartina alterniflora in a salt marsh in Barataria Bay, Louisiana. Estuar Coast Mar Sci 4:59-64

Pennings SC, Stanton LE, Brewer JS (2002) Nutrient effects on the composition of salt marsh plant communities along the southern Atlantic and Gulf coasts of the United States. Estuaries 25:1164-1173

Rabalais NN (2002) Nitrogen in aquatic ecosystems. Ambio 31:102-112

> Rydin H, Clymo RS (1989) Transport of carbon and phosphorus compounds about Sphagnum. Proc R Soc Lond B 237: 63-84
Silliman BR, Bertness MD (2004) Shoreline development drives invasion of Phragmites australis and the loss of plant diversity on New England salt marshes. Conserv Biol 18:1424-1434

Slocum MG, Mendelssohn IA (2008) Effects of three stressors on vegetation in an oligohaline marsh. Freshw Biol 53: 1783-1796

Smalley AE (1959) The role of two invertebrate populations, Littorina irrorata and Orchelimum fidicinum in the energy flow of a salt marsh ecosystem. PhD dissertation, University of Georgia, Athens

Sullivan MJ, Daiber FC (1974) Response in production of cord grass, Spartina alterniflora, to inorganic nitrogen and phosphorus fertilizer. Chesapeake Sci 15:121-123

Swenson EM, Chuang WS (1983) Tidal and subtidal water volume exchange in an estuarine system. Estuar Coast Shelf Sci 16:229-240

Trahan L, Bradley JJ, Morris L (1990) Soil survey of St. Tammany Parish, Louisiana. U.S. Department of Agriculture, Soil Conservation Service, Washington, DC, in cooperation with Louisiana Agricultural Experiment Station and Louisiana State Soil and Water Conservation Committee, Baton Rouge, LA

Turner RE (1990) Landscape development and coastal wetland losses in the northern Gulf of Mexico. Am Zool 30: 89-105

> Turner RE, Rabalais NN (1991) Changes in Mississippi River water quality this century. Bioscience 41:140-147

Turner RE, Rabalais NN, Justic D (2006) Predicting summer hypoxia in the northern Gulf of Mexico: riverine N, P, and Si loading. Mar Pollut Bull 52:139-148

Tyler G (1967) On the effect of phosphorus and nitrogen supplied to Baltic shore-meadow vegetation. Bot Notiser 120: 433-447

Vaithiyanathan P, Richardson CJ (1999) Macrophyte species changes in the everglades: examination along a eutrophication gradient. J Environ Qual 28:1347-1358

Valiela I, Teal JM (1974) Nutrient limitation in salt marsh vegetation. In: Reimold RJ, Queen WH (eds) Ecology of halophytes. Academic Press, New York, NY

> Valiela I, Teal JM, Sass WJ (1975) Production and dynamics of salt-marsh vegetation and effects of experimental treatment with sewage sludge - biomass, production, and species composition. J Appl Ecol 12:973-981

> van Heerwaarden LM, Toet S, Aerts R (2003) Nitrogen and phosphorus resorption efficiency and proficiency in six sub-arctic bog species after 4 years of nitrogen fertilization. J Ecol 91:1060-1070

Visser JM, Sasser CE, Chabreck RH, Linscombe RG (1998) Marsh vegetation types of the Mississippi River deltaic plain. Estuaries 21:818-828

Welder FA (1959) Processes of deltaic sedimentation in the lower Mississippi River. Coastal Studies Institute Technical Report. Louisiana State University, Baton Rouge, LA

Whigham DF, Nusser SM (1990) The response of Distichlis spicata (L.) Green and Spartina patens (Ait.) Muhl. to nitrogen fertilization in hydrologically altered wetlands. In: Whigham DF, Good RE, Kvet J (eds) Wetland ecology and management: case studies. Kluwer Academic Publishers, Dordrecht, p 31-38

Wigand C, Thursby GB, McKinney RA, Santos AF (2004) Response of Spartina patens to dissolved inorganic nutrient additions in the field. J Coast Res 20(Spec Issue 45): $134-149$ 